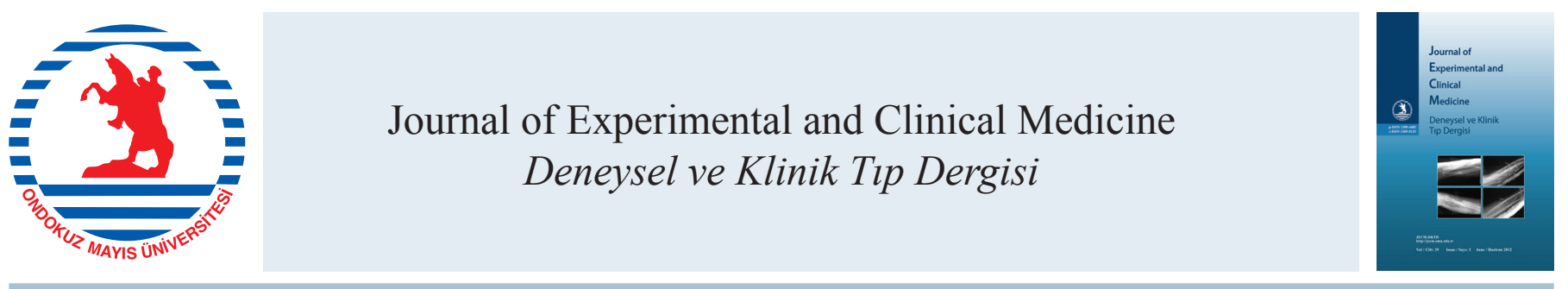

Olgu Sunumu / Case Report

doi: $10.5835 /$ jecm.omu.29.02.015

\title{
Birincil kemik lenfoması
}

\section{Primary bone lymphoma}

\author{
Murat Elli*a, Halil Çelik ${ }^{\mathrm{a}}$, Ayhan Dağdemir ${ }^{\text {a }}$, Nevzat Dabak ${ }^{\mathrm{b}}$, M. Bekir Selçuk ${ }^{\mathrm{c}}$, Fevziye C. Tosun ${ }^{\text {d, Bedri Kandemir }}{ }^{\mathrm{e}}$ \\ ${ }^{a}$ Ondokuz Mayıs Üniversitesi, Tip Fakültesi, Çocuk Onkoloji Anabilim Dall, Samsun, Türkiye \\ ${ }^{b}$ Ondokuz Mayıs Üniversitesi, Tıp Fakültesi, Ortopedi ve Travmatoloji Anabilim Dalı, Samsun, Türkiye \\ c Ondokuz Mayıs Üniversitesi, Tıp Fakültesi, Radyoloji Anabilim Dall, Samsun, Türkiye \\ ' Ondokuz Mayıs Üniversitesi, Tıp Fakültesi, Nükleer Tıp Anabilim Dall, Samsun, Türkiye \\ e Ondokuz Mayıs Üniversitesi, Tip Fakültesi, Patoloji Anabilim Dall, Samsun, Türkiye
}

\begin{tabular}{|c|c|}
\hline \multicolumn{2}{|c|}{ MAKALE BİLGILERİ } \\
\hline \multicolumn{2}{|c|}{ Makale geçmişi } \\
\hline Geliş tarihi & : 26 / 04 / 2011 \\
\hline Kabul tarihi & $: 14$ / 05 / 2011 \\
\hline
\end{tabular}

\section{ÖZET}

Kemiğin primer lenfoması nadir görülen bir tümördür. Yaygın büyük hücreli lenfoma en sık histolojik alt tiptir. Biz burada 16 yaşında bir çocukta femura alt ucundan kaynaklanan, sistemik kemoterapi ile tedavi edilen yaygın büyük hücreli lenfoma olgusunu sunduk. J. Exp. Clin. Med., 2012; 29:155-158

\section{* Yazışma Adresi:}

Murat Elli

Ondokuz Mayıs Üniversitesi,

Tıp Fakültesi,

Çocuk Onkoloji Bilim Dalı,

Samsun, Türkiye

e-posta: ellimurat@yahoo.com

\begin{abstract}
Primary bone lymphoma is a rare malignancy of the bones. Diffuse large B-cell lymphoma is by far the most common histology presenting as primary bone lymphoma. We presented a 16-years old child with diffuse large B-cell lymphoma on distal femur. He was treated with systemic chemotherapy.

J. Exp. Clin. Med., 2012; 29:155-158
\end{abstract}

\section{Anahtar Kelimeler:}

Yaygın büyük hücreli lenfoma

Birincil kemik tümörü

Çocukluk çağı

Kemoterapi

$\mathrm{PET} / \mathrm{BT}$

Femur

\section{Key words:}

Diffuse large B-cell lymphoma

Primary bone tumor

Childhood

Chemotherapy

PET/CT

Femur

\section{Giriş}

Birincil kemik lenfoması (BKL), lenfoid maligniteler arasında oldukça nadir bir gruptur ve ilk başvuru sırasında sistemik hastalık bulgusu olmaksızın kemik veya kemik iliğine sınırlı bir lenfoma olarak tanımlanmaktadır. Tüm Hodgkin dışı lenfomalar içinde $\% 1$ den az görülür ve tüm kemik malignitelerinin \% 7 si ve ekstranodal lenfomaların \% 4-5 ini oluşturur (Suryanarayan, 1999). BKL'nın büyük kısmını Hodgkin-dışı lenfoma oluşturur ve en sık alt tipi "Yaygın Büyük Hücreli Lenfoma"dır (Ramadan ve ark., 2007; Power ve ark., 2008). Burada kemoterapi ve cerrahi ile başarılı şekilde tedavi edilen femur alt uçta yerleşim gösteren yaygın büyük hücreli lenfoma olgusu sunulmuştur.

\section{Olgu}

16 yaşında erkek hasta sol dizde ağrı ve şişlik yakınmasıyla 
getirildi. Bir ay önce sol dizini çarpması sonrasında şişlik ve ağrı oluşmuş. İzleminde şikâyetlerinin artması üzerine fakültemiz ortopedi polikliniğine başvurmuştur. Fizik incelemesinde; genel durumu iyi, bilinci açıktı. Sol dizde düzensiz şişlik ve hassasiyet mevcuttu. Sol diz çapı: $39 \mathrm{~cm}$ sağ diz çapı: $35 \mathrm{~cm}$ ölçüldü (Şek. 1), yanıtları fleksördü.
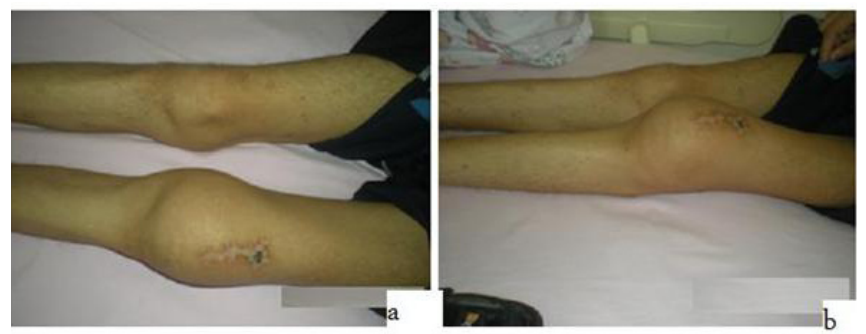

Şek. 1 (a ve b). Sol dizde düzensiz şişlik ve hassasiyet

Lenfadenopati (LAP) ve hepatosplenomegali (HSM) saptanmadi. Diğer sistem muyeneleri doğal. Dört kardeşten en büyüğü olan hastanın öz ve soy geçmişinde özellik yoktu. Radyolojik görüntüleme incelemelerde (X-ray, BT, MR) "sol femur distal metafiz medialinde litik lezyon ve yumuşak doku tutulumu" saptandı (Şek. 2). Sedimantasyon $39 \mathrm{~mm} / \mathrm{h}$, LDH: $522 \mathrm{U} / \mathrm{L}$ diğer laboratuvar incelemelerinde özellik yoktu. Kemik iliği aspirasyon incelemelerinde malign hücre görülmedi.
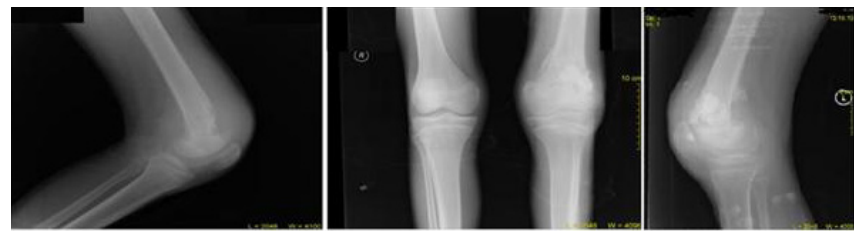

Şek. 2. Direk kemik grafisinde femur alt uçta litik lezyon

\section{Ekstremite BT}

Sol femur distal metafizden epifize uzanan, kemikte anterolaterale deplase parçalı fraktüre ve kortekste incelme, düzensizlik ve yer yer devamsızlığa neden olan, düzensiz konturlu yaklaşık $67 \times 43 \mathrm{~mm}$ en geniş transvers boyutlarda yumuşak doku kitlesi izlenmiş olup lezyon ekleme açılmamaktadır.

\section{Tüm vücut FDG PET}

Sol femur $1 / 2$ distalinde kortikal/perikortikal yayılım gösteren destrüktif lezyonda hastanın birincil tanısı (lenfoma) ile uyumlu yoğun hiperglikometabolik aktivite izlendi (Şek. 3). Tedavi sonrası yapılan değerlendirme positron emission tomography'de (PET-BT) kemoterapiye tam cevap saptand 1 (Şek. 5, 6).

\section{Kemik sintigrafisi}

Kanlanma ve kan havuzu görüntülerinde sol femur $1 / 2$ distal epifizometadiafizer bölgede santrali fotopenik periferal aktivite artışı izlenmektedir. 3 saat sonra alınan tüm vücut ve bölgesel statik görüntülerde sol femur distal epifizometadiafizer bölgede santrali fotopenik ekspansif karakterde periferal osteoblastik aktivite artışı mevcuttur; ayrıca sol tibia epifizometafizer bölgede ve sol kokso-femoral eklem bölgesinde regüler hafif-orta derecede osteoblastik aktivite artışları izlenmiştir (Şek. 4).

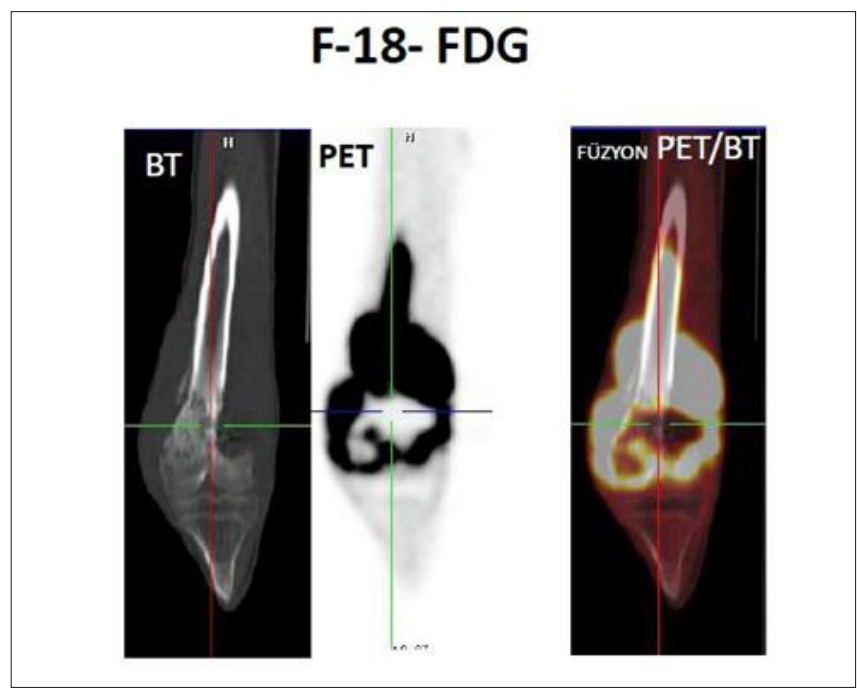

Şek. 3. Tedavi öncesi PET BT yoğun hiperglikometabolik aktivite

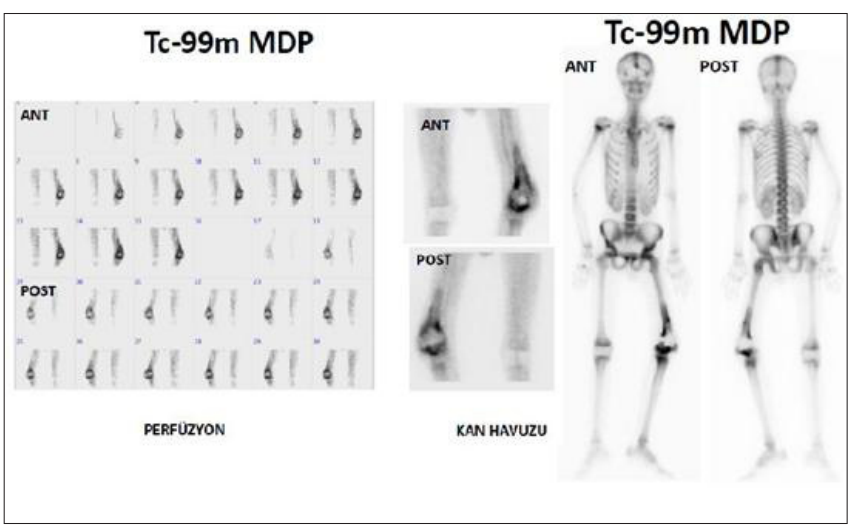

Şek. 4. Tedavi öncesi kemik sintigrafisi: Sol femur distal epifizometadiafizer bölgede santrali fotopenik ekspansif karakterde periferal osteoblastik aktivite artışı

Hastadan alınan "tru-cut" kemik biyopsisinde hazırlanan kesitlerde yumuşak doku örneklerinin tamamını infiltre etmiş, farklı büyüklükte ve şekilde yer yer kromatinden zengin veziküle nükleuslu atipik lenfoid hücrelerden oluşan tümör izlendi. İmmünohistokimyasal çalışmada tümör hücreleri LCA, CD20, CD79 ile kuvvetli pozitif boyanmıştır. Sonuç olarak, diffuz büyük hücreli lenfoma olarak değerlendirildi (Şek. 7, 8).

Hasta, klinik ve radyolojik değerlendirme sonucu Evre II, LDH>500 olması nedeniyle risk grubu III kabul edildi. Hastaya ikişer kür AA, BB, CC içeren BFM kemoterapi protokolü uygulandi. Radyolojik ve sintigrafik (PET-BT) ile remisyonda olduğu gösterilen hastaya lokal kontrol amaciyla cerrahi rezeksiyon yapıldı, protez kondu (Şek. 5, 6). Hasta tedavi sonras1 9. ayda halen remisyonu devam etmektedir.

\section{Tartışma}

Tüm lenfomalar çocukluk çağı kanserlerinin yaklaşık \% 15-20'sini oluşturur. Dünyada lösemi ve santral sinir sistemi (SSS) tümörlerinden sonra 3. sirada iken yurdumuzda lösemilerin ardından 2. sıklıktadır. 5 yaş altındaki sıklığı $\%$ 3 iken 15-19 yaşda \% 24'e ulaşmaktadır. Tüm lenfomoların yarıdan fazlası Hodgkin-dışı lenfomadır.

Birincil kemik lenfoması (BKL), lenfoid malignensiler arasında oldukça nadir bir gruptur ve ilk başvuru sırasında 


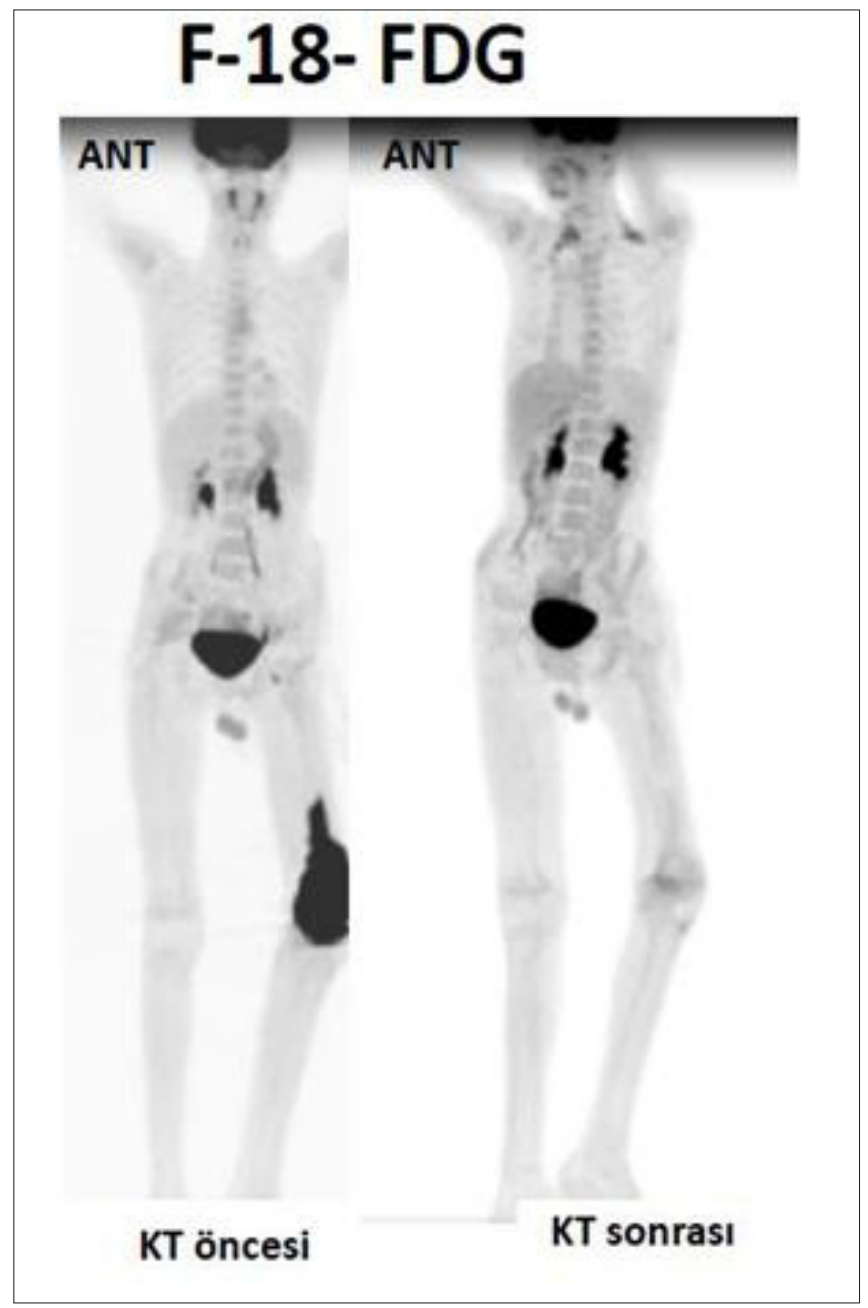

Şek. 5. Kemoterapi öncesi ve sonrası PET-BT görüntülemesi. Tedavi öncesi PET-BT incelemesi ile karşılaştırıldığında; sol femur $1 / 2$ distalinde destrüktif yumuşak doku kitlesinin bu çalışmada boyutlarının belirgin derecede azaldığı ve kortikal perikortikal minimal heterojen metabolik aktivite artışı (SUVmaks: 2,37; geç SUVmaks: 2,19).

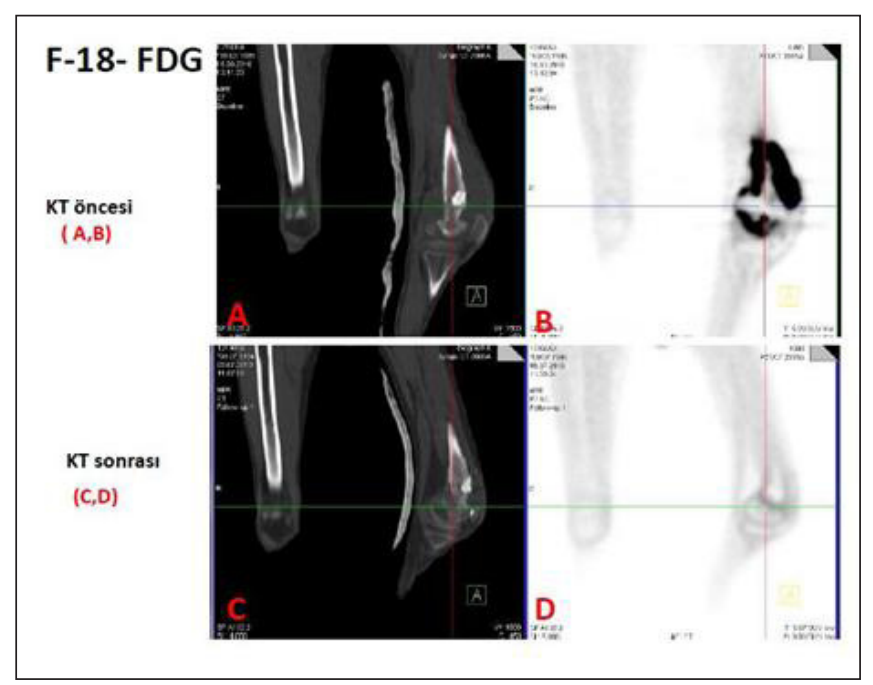

Şek. 6. Kemoterapi öncesi ve sonrası PET-BT görüntülemesi sol femur $1 / 2$ distalinde lokalize kitle boyutlarında küçülme ve minimal heterojen metabolik aktivite artışı; tama yakın metabolik tedavi yanıtı ve beraberinde reaktif değişiklikler.

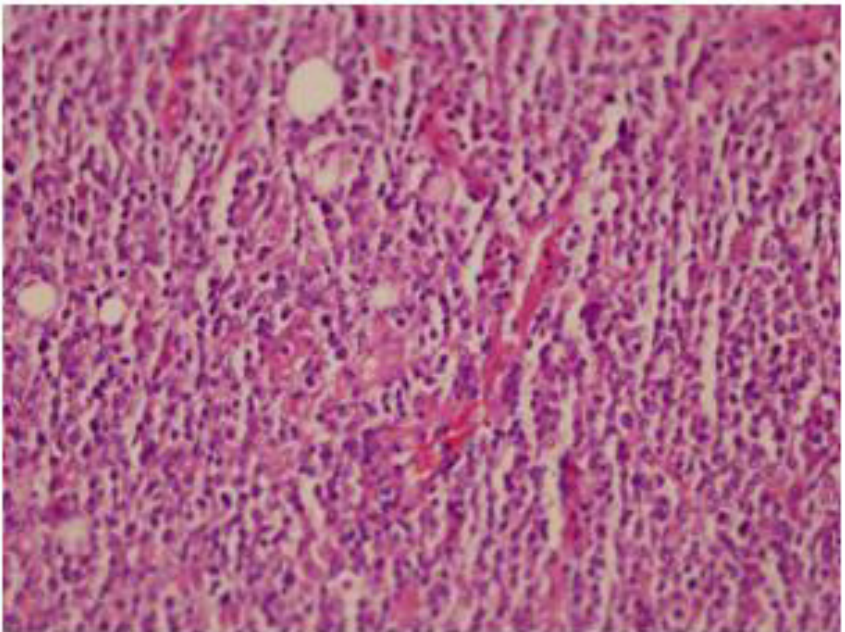

Şek. 7. İri, kromatinden zengin nükleuslu atipik lenfoid hücrelerden kurulu tümöral gelişim (H\&E, x200)

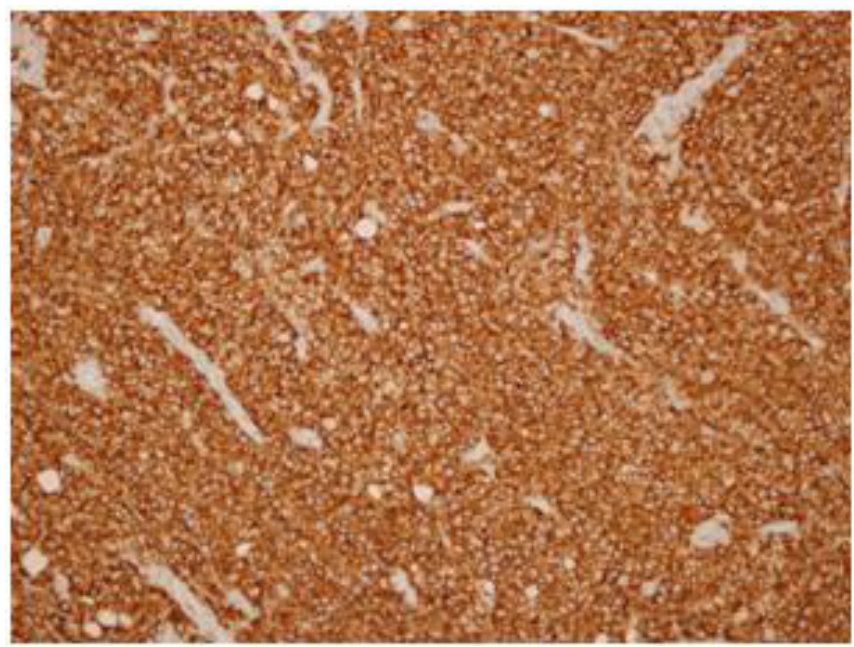

Şek. 8. Lenfoid hücrelerde immünohistokimyasal olarak CD20 pozitifliği (DAB, X100)

sistemik hastalık bulgusu olmaksızın kemik veya kemik iliğine sınırlı bir lenfoma olarak tanımlanmaktadır. Parker ve Jackson birincil kemik lenfomasını, ilk olarak 1939 da, immünohistokimyasal B hücre kökenli olduğu kesinleştirilene kadar kemiğin retiküler hücreli sarkomu olarak tanımlamıştır (Parker ve Jackson, 1939). Görülme sıklığı 5. ve 6. dekadlarda pik yapmakta olup (ortalama yaş: 44), literatürde 1,3-1,8/1 oranında erkek predominansı bildirilmiştir. BKL kemik korteksi ve/veya etrafi yumuşak dokuda tutulum olup olmamasına bakılmaksızın kemiğin malign lenfoid infiltrasyonu olarak tanımlanmıştır; uzak viseral yapılarda ya da bölgesel lenf bezlerinde infiltrasyon olmamalıdır (Boston ve ark., 1974; Petit ve ark., 1990). S1klıkla lokalize kemik ağrısı, şişlik, patolojik fraktür ve nadiren kitle lezyonu olarak karşımıza çıkar. Hastalık genellikle femur tibia başta olmak üzere uzun kemikleri tutar; kemiğin tüm bölgeleri tutulabilir, ancak santral tutulum yaygındır. Siklıkla alt ekstremite tutlumu görülür. Metafiz kemik iliği dağılımına bağlı olarak öncelikle etkilenen bölgedir (Suryanarayan ve ark., 1999, Bhagavathi ve ark., 2009; Jawad ve ark., 2010).

Patolojik olarak lenfoma tanıs1 koymak, lezyonun mikst hücre yapısından dolayı zordur. Ancak trabeküler yıkım yapmadan kemiği tutan tümörlerde malign lenfoma olasılığı yüksektir. Histolojik alt tip olarak "yaygın B hücreli 
lenfomanın" erken yaşlarda daha iyi prognoza sahip olduğu saptanmıştır (Ramadan ve ark., 2007, Jawaad ve ark., 2010). İmmünohistokimyasal araştırmalar ile hücre tipi belirlenebilir. Ayırıcı tanıda kemiğin tüm yuvarlak hücreli lezyonları yer almakla birlikte, en önemlisi Ewing sarkomu ile ayrımının yapılmasidir.

Tedavi; radyoterapi, kemoterapi ve cerrahiden oluşan multimodal yaklaşımı içerir. Sınırlı hastalıkta kombine tedavi ile uzun süreli yaşam süreleri sağlanabilmektedir. Erişkin yaş olgulara göre çocukluk yaşında kemoterapi ile oldukça iyi sağ kalım oranları elde edilmiştir. Çok az sayıda olgu için lokal radyoterapi gereksinimi görülmüştür (Suryanarayan ve ark., 1999). Tanı ve tedaviye cevabın değerlendirilmesinde PET-BT giderek daha önemli bir yer tutmaktadır (Bakhshi ve ark., 2008). Tedavi sonrası yeni kemik oluşumu sırasındaki dokular PET-BT'de yanlış pozitif bulgulara yol açabileceği için diğer görüntüleme yöntemleri ile de doğrulanmalıdır (Reddy ve Greer, 2010).

\section{KAYNAKLAR}

Bakhshi, S., Singh, S., Thulkar, S., 2008. Bone involvement in pediatric non-Hodgkin's lymphomas. Hematology. 13, 348-351.

Bhagavathi, S., Micale, M.A., Les, K., Wilson, J.D., Wiggins, M.L., Fu, K., 2009. Primary bone diffuse large B-cell lymphoma clinicopathologic study of 21 cases and review of literature. Am. J. Surg. Pathol. 33, 1463-1469.

Boston, H.C. Jr, Dahlin, D.C., Ivins, J.C., 1974. Cupps RE. Malignant lymphoma (so-called reticulum cell sarcoma) of bone. Cancer. 34, 11311137.

Jawad, M.U., Schneiderbauer, M.M., Min, E.S., Cheung, M.C., Koniaris, L.G., Scully, S.P., 2010. Primary lymphoma of bone in adult patients. Cancer. 116, 871-879.

Parker, J.W., Jackson, H., 1939. Primary reticulum cell sarcoma of bone. Surg. Gynecol. Obstet. 68, 45-53.

Pettit, C.K., Zukerberg, L.R., Gray, M.H., Ferry, J.A., Rosenberg, A.E., Harmon, D.C., Harris, N.L., 1990. Primary lymphoma of bone. A B-cell neoplasm with a high frequency of multilobated cells. Am. J. Surg. Pathol. 14, 329-334.

Power, D.G., McVey, G.P., Korpanty, G., Treacy, A., Dervan, P., O'Keane, C., Carney, D.N., 2008. Primary bone lymphoma: Single institution case series. İrish J. Med. Sci. 177, 247-251.

Ramadan, K.M., Shenkier, T., Sehn, L.H., Gascoyne, R.D., Connors, J.M., 2007. A clinicopathological retrospective study of 131 patients with primary bone lymphoma: A population-based study of successively treated cohorts from the British Columbia Cancer Agency. Ann. Oncol. $18,129-135$.

Reddy, N. Greer, J.P. 2010. Primary bone lymphoma: A set of unique problems in management. Leuk. Lymphoma. 5, 1-2.

Suryanarayan, K., Shuster, J.J., Donaldson, S.S., Hutchison, R.E., Murphy, S.B., Link, M.P., 1999. Treatment of localized primary non-Hodgkin's lymphoma of bone in children: A pediatric oncology group study. J. Clin. Oncol. 17, 456-459. 